\title{
THE IMPACT OF CORRUPTION DISTANCE ON OWNERSHIP STRATEGIES OF SPANISH AND PORTUGUESE MNES
}

\section{ABSTRACT}

The ownership strategy of foreign subsidiaries is an important decision for multinational enterprises (MNEs). Previous research has analyzed the effect of country dimensions on this strategy, both from the home and the host country. In this paper we delve into the effect of differences between home and host country on the MNEs' ownership strategies. Empirically, we analyze the influence of corruption distance on the ownership strategies of Spanish and Portuguese MNEs, using data from 3,941 foreign subsidiaries. We found that the higher the absolute corruption distance between Spain (or Portugal) and the host country, the higher the ownership controlled by MNEs. However, when the host is more corrupt than the home country, MNEs have a lower ownership level in the local subsidiaries.

Keywords: Corruption Distance; Ownership Strategy; Home-Host Differences; Portugal; Spain.

\section{O IMPACTO DA DISTÂNCIA DE CORRUPÇÃO NAS ESTRATÉGIAS DE POSSE DE PMES ESPANHOLAS E PORTUGUESAS}

\section{RESUMO}

A estratégia de posse de subsidiárias no estrangeiro é uma importante decisão para empresas multinacionais (EMNs). Pesquisa anterior analisou o efeito de dimensões do país na estratégia de posse, quer do país de origem quer do país receptor. Neste artigo escrutinamos o efeito das diferenças entre o país de origem e o país receptor na estratégia de posse de EMNs. Empiricamente, analisamos a influência da distância de corrupção nas estratégias de posse de EMNs espanholas e portuguesas, usando dados de 3.941 subsidiárias no estrangeiro. Concluímos que quanto maior a distância de corrupção (em valor absoluto) entre Espanha (ou Portugal) e o país receptor, maior o nível de posse detido pela EMN. Contudo, quando o receptor é mais corrupto que o país de origem, as EMNs têm detêm um nível de posse mais baixo nas subsidiárias locais.

Palavras-chave: Distância de Corrupção; Estratégia de Posse; Diferenças Origem-Destino; Portugal; Espanha. 


\section{EL IMPACTO DE LA DISTANCIA DE CORRUPCIÓN EN LAS ESTRATEGIAS DE PROPIEDAD DE LAS EMN DE ESPAÑOLAS Y PORTUGUESAS}

\section{RESUMEN}

La estrategia de propiedad de subsidiarias en el extranjero es una importante decisión para empresas multinacionales (EMN). Investigación anterior analizó el efecto de dimensiones del país en la estrategia de posesión, tanto del país de origen como del país receptor. En este artículo escudriñamos el efecto de las diferencias entre el país de origen y el país receptor en la estrategia de propiedad de EMN. Empíricamente, se analiza la influencia de la distancia de la corrupción en las estrategias de propiedad de las multinacionales españolas y portuguesas, utilizando los datos de 3.941 filiales en el extranjero. Llegamos a la conclusión de que cuanto más grande es la distancia de la corrupción (en valor absoluto) entre España (o Portugal) y el país anfitrión, más grande es el nivel de participación de las EMN. Sin embargo, cuando el recetor es más corrupto que el país de origen, las EMN tienen un nivel de posesión más bajo en las subsidiarias locales.

Palabras-clave: Distancia de Corrupción; Estrategia de Propiedad; Diferencias Origen-Destino; Portugal; España.

\footnotetext{
${ }^{1}$ MSc in Business Management from University of Coimbra. Faculty of Economics, University of Coimbra. Portugal. E-mail: marianafaria1991@gmail.com

${ }^{2} \mathrm{PhD}$ in Management Science from University of Barcelona. Assistant Professor at Faculty of Economics, University of Coimbra. Researcher at CeBER - Centre for Business and Economics Research. Portugal. E-mail: $\underline{\mathbf{f c} @ \mathbf{f e . u c} . \mathbf{p t}}$

${ }^{3} \mathrm{PhD}$ in Business Management from University of Coimbra. Assistant Professor at School of Technology and Management, Polytechnic Institute of Leiria. Researcher at CARME - Centre of Applied Research in Management and Economics. Portugal. E-mail: nuno.m.reis@ipleiria.pt
} 


\section{INTRODUCTION}

When deciding to conduct foreign direct investments (FDI) in a foreign market, multinational enterprises (MNEs) need to decide on the ownership strategy (Stopford \& Wells, 1972; Godinez \& Liu, 2015). Deciding on how to enter in a different market determines the success of international operations (Stopford \& Wells, 1972; Chari \& Chang, 2009; Duanmu, 2011; Di Guardo, Marrocu \& Paci, 2016). The extent of ownership in the foreign subsidiaries determines such issues as resource commitment, risk, investment return and control (Anderson \& Gatignon, 1986; Luo, 2001). In fact, international ownership strategy is a central issue in economic theory and has become one of the main objects of study in International Business (IB) research (Duanmu, 2011; Wang \& Larimo, 2018). For instance, the choice between wholly owned subsidiary (WOS) and joint venture $(\mathrm{JV})$ has been subject of multiple investigations and many factors have been found to have an impact on the decision, such as the international experience of the firm, cultural distance between the investing country and the host country and other transaction cost related characteristics (Duanmu, 2011). Recently, scholars have recommended exploring the effect of the quality of the host country's "governance infrastructure" (Slangen \& Van Tulder, 2009, p. 277) on the ownership strategies. One of the most crucial dimensions, due to its impact on economy, is corruption (Di Guardo, Marrocu \& Paci, 2016).

Corruption has been widely researched in IB literature (Cuervo-Cazurra, 2016). Corruption, commonly defined as "the misuse of public office for private gain" (Svensson, 2005, p. 20) is posited to have a negative impact on society and on economic activity (Voyer \& Beamish, 2004). Arguments that corruption inhibits private investment and economic growth (Shleifer \& Vishny, 1993; Mauro, 1995), reduces the legitimacy of governments (Anderson \& Tverdova, 2003) and affects political and social stability (Gupta \& Abed, 2002), are often used to demonstrate that corruption has a negative impact on firms' performance and thereby on the economic development of countries. Nevertheless, the effect of corruption on firms' decisions in not completely understood (CuervoCazurra \& Genc, 2011). Recently, scholars have been exploring how the differences in corruption among countries influence MNEs' ownership strategies (Tekin-Koru, 2006; Duanmu, 2011). The difference in the corruption between the home and host countries refers to the concept of corruption distance (Eden \& Miller, 2004). This is a relatively new concept so its impact on ownership strategies is still very little known. Although the number of empirical studies on corruption distance and its effects is small, the results show that the greater the corruption distance between the home country and the host country, the greater the likelihood that MNEs will prefer WOS over JV (TekinKoru, 2006; Duanmu, 2011). However, other studies indicate that greater corruption distance increases the likelihood of firms selecting a shared ownership of the subsidiary (Karhunen \& Ledyaeva, 2012). Thus, the conflicting results in the literature offer a gap for further research that we try to address in this paper. Furthermore, the existing studies on corruption distance and ownership strategies analyze emerging countries, namely China (Duanmu, 2011) and Russia (Karhunen \& Ledyaeva, 2012) thereby warranting the need for analysis of MNEs from developed countries.

In this paper we explore the effect of corruption distance on ownership strategies of Spanish and Portuguese MNEs. On one hand, we investigate whether increases in corruption distance between Spain or Portugal and a host country lead to higher ownership levels by Spanish and Portuguese MNEs in foreign subsidiaries. On the other hand, we explore the effect of the direction of corruption distance on ownership strategies, advancing different impacts depending on whether the host country is more or less corrupt than Spain or Portugal. Empirically, we analyze 3,941 foreign subsidiaries of Spanish and Portuguese MNEs (3,139 Spanish subsidiaries and 802 Portuguese subsidiaries), located in 68 countries. Using generally accepted data on corruption (Ferreira et al., 2017), we found broad support for the proposed effects of corruption on ownership strategies.

We contribute to the extant knowledge in three manners. First, we contribute to a better understanding of corruption distance and its effect. While a wealth of research on corruption exist, the effect of corruption distance (i.e. the differences between the corruption levels of the two countries) is still underexplored. We shed light on this issue by advancing a model that posits a greater corruption distance will influence firms to choose greater ownership. We argue that MNEs cope with the increased uncertainty caused by large differences by choosing to control more ownership.

Second, we contribute to the literature by empirically testing a relatively novel concept, the direction of corruption distance, extending the grasp of country-level asymmetrical differences. We conclude that the direction of corruption distance matters and influences the ownership strategy followed by MNEs. Specifically, we conclude that negative corruption distance (i.e. a host country with higher corruption levels than the home country) leads MNEs to seek a lower ownership, thus requiring a local partner with the necessary knowledge to perform the corrupt activities.

Finally, we contribute to a better understanding of the strategic choices of Spanish and Portuguese MNEs, in particular how corruption distance influences their decisions regarding the control exerted over foreign subsidiaries. This is an underexplored research setting that requires a greater understanding due to its idiosyncrasies. While Spain and Portugal have lower 
corruption levels than emerging countries, they have higher corruption levels than other European Union countries. This suggests that Spanish and Portuguese MNEs may be influenced by corruption distance in a different way than the one posited in the literature.

The paper is structured as follows. We present the literature review and introduce the hypotheses in following section. We then describe the dataset and the research methodology in the third section and present the results of our empirical study in the fourth section. We conclude with a broad discussion of the implications of our findings, the limitations of the paper and possible avenues for future research.

\section{LITERATURE REVIEW AND HYPOTHESES}

\section{Corruption and FDI}

Corruption inhibits private investment and economic growth (Shleifer \& Vishny, 1993; Mauro, 1995), reduces the legitimacy of government (Anderson \& Tverdova, 2003) and affects political and social stability (Gupta \& Abed, 2002). The evidence shows that corruption represents a challenge not only for transition economies but also for developed countries (Bellos \& Subasat, 2012). The World Economic Forum, for instance, estimates that the cost of corruption represents more than 5\% of global GDP (approximately US\$2.6 trillion) and increases the cost of doing business by up to $10 \%$ on average (OECD, 2014).

Corruption and its effects, especially on FDI, are a central issue in IB literature (Duanmu, 2011). However, there is no agreement concerning the effect of corruption on FDI (Cuervo-Cazurra, 2008). There are theoretical arguments suggesting a negative effect of corruption on FDI but there are also arguments suggesting a positive effect (Duanmu, 2011). Although there is evidence supporting both views of corruption, the empirical evidence suggests a prevailing negative impact on FDI (Wei, 2000a; Wei, 2000b; Habib \& Zurawicki, 2002; Lambsdorff, 2003; Voyer \& Beamish, 2004; Cuervo-Cazurra, 2006; Duanmu, 2011).

The relationship between corruption and ownership strategies of MNEs has received less attention in the literature (Duanmu, 2011; Di Guardo, Marrocu \& Paci, 2016). One of the earliest studies on this topic was conducted by Smarzynska and Wei (2000). In their cross-sectional analysis of FDI in Eastern Bloc countries, high levels of corruption in the host country are posited to lead to a preference of shared control, such as JVs over WOS (Smarzynska \& Wei, 2000). The authors argue that a lower level of ownership helps to reduce commitment and risk associated with the investment and may also be a sensible reaction to the uncertainty experienced in these transition countries (Smarzynska \& Wei, 2000). Based on institutional theory, Uhlenbruck, Rodriguez, Doh and Eden (2006) suggest that MNEs respond to pervasive and arbitrary corruption in host countries by selecting specific modes of entry. Analyzing data on telecommunications development projects in emerging economies, the authors find that the more pervasive the level of corruption in the host country, the greater the possibility of MNEs choosing WOS over JV. Finally, Di Guardo, Marrocu and Paci (2016) found that the relationship between the level of corruption of the host country and the firm's probability of choosing full control mode in cross-border mergers and acquisitions is U-shaped. Moreover, the authors argue that industry relatedness between acquirer and target and the level of connectivity between home and host countries moderate the relationship between the level of corruption of the host country and the level of control (Di Guardo, Marrocu \& Paci, 2016).

\section{Corruption distance and ownership strategies}

Corruption distance is defined as the difference in pervasive and arbitrary corruption of the public sector between home and host countries (Eden \& Miller, 2004). The corruption distance offers another perspective to analyze the effect of corruption on MNEs' decisions. It allows to consider simultaneously the characteristics of home and host countries (Eden \& Miller, 2004). Host country corruption has a direct impact on FDI but also an indirect effect: formal institutions in the host country may interact with institutions in the home country, which may themselves interact with informal institutions (Holmes et al., 2013), affecting the way foreign investors act (Cuervo-Cazurra, 2008). Thus, the level of uncertainty and the costs associated with corruption may vary depending on the host country, on the home country of the investors and on the differences in the corruption levels between the home and the host countries (Cuervo-Cazurra, 2006). Using the corruption distance concept, Tekin-Koru (2006) and Duanmu (2011) provided two of the few studies on the impact of corruption distance on entry modes. Both studies suggest that the higher the corruption distance between the home country and the host country, the greater the preference of MNEs for WOS over JV (Tekin-Koru, 2006; Duanmu, 2011).

When the levels of corruption of the host country are too high, corruption is considered institutionalized (Gabbioneta et al., 2013). In this case, public and governmental authorities establish regulations which facilitate corruption and represent a source of income for them (Cheung, 1996). The institutional environment stimulates forms of direct corruption, by facilitating its occurrence and providing opportunities (Gabbioneta et al., 2013; Neu, Rahaman \& Martinez , 2013). MNEs from countries which have 
a large corruption distance may need to warrant country-specific knowledge to operate in a dissimilar country - from a corruption perspective (Di Guardo, Marrocu \& Paci, 2016). However, given the institutionalized corruption, the cost of maintaining a local partner and choosing a shared form of control outweighs the benefits making firms prefer WOS over JV (Di Guardo, Marrocu \& Paci, 2016).

MNEs' decide to have a higher level of ownership to reduce the costs and the risks (Di Guardo, Marrocu \& Paci, 2016). From the investing MNE's perspective, particularly if the firm is from a transparent country, WOS provides a higher level of control over the way the business is conducted (Di Guardo, Marrocu \& Paci, 2016) and ensures the respect of the values of the parent-firm (Gaur \& Lu, 2007). The extra costs the investing firm may incur in addressing corrupt environments can be justified by considering the implications of protecting and sustaining its global image (Di Guardo, Marrocu \& Paci, 2016). A higher control allows firms to reduce the costs associated with operating alone (Madhok, 1997) and makes possible for foreign investors to access and acquire organizationally embedded knowledge (Barkema \& Vermeulen, 1998). Taking into account these arguments, we advance:

Hypothesis 1. The greater the corruption distance between the home country (Portugal or Spain) and the host country, the greater the ownership MNEs will seek in local subsidiaries.

\section{Direction of corruption distance}

The level of corruption in the host country has different effects on foreign investors, depending on the level of corruption of the home country (Godinez \& Liu, 2015). The effects of corruption on MNEs' decisions vary according to the direction of corruption distance (Duanmu, 2011). When the levels of corruption in the host country are higher than the levels of corruption in the home country there is a negative corruption distance between them (Godinez \& Liu, 2015). Conversely, when the destination is less corrupt than the home country there is a positive corruption distance between them (Godinez \& Liu, 2015). MNEs perceive and respond to corruption differently, according to their perceptions regarding the corruption level of their home country (Godinez \& Liu, 2015). Several studies suggest that MNEs from more transparent countries avoid investing in highly corrupt countries (Habib \& Zurawicki, 2002). When the country of origin has low levels of corruption many firms may not have the knowledge and the skills necessary to deal with corruption (Pajunen, 2008). On the other hand, firms from highly corrupt environments may not be as sensitive to high corruption levels abroad
(Godinez \& Liu, 2015). A high level of corruption in the home country helps firms to develop the skills needed to deal with the phenomenon of corruption (Cuervo-Cazurra, 2006). In this case, corruption is not an obstacle to investment and may even by a source of competitive advantage for these firms, comparing to those from transparent countries (Suchman, 1995; Cuervo-Cazurra, 2006; Cuervo-Cazurra \& Genc, 2008).

When investing in a more corrupt country MNEs may prefer to have a local partner (Godinez \& Liu, 2015). Higher corruption represents higher uncertainty, higher risk and higher costs for MNEs (Di Guardo, Marrocu \& Paci, 2016). To deal with these problems, MNEs may establish a partnership with a local firm with market knowledge, sharing the risks and the costs associated with the investment and the control over the business operations (Smarzynska \& Wei, 2000; Uhlenbruck et al., 2006). The establishment of a partnership with a local firm may be the only way foreign investors have to access to the market (Smarzynska \& Wei, 2000; Uhlenbruck et al., 2006) and achieve the necessary external legitimacy (Beamish, 1985). Therefore, we hypothesize that when the direction of corruption distance is negative, the effect of corruption distance on ownership strategy of MNEs may diminishes.

When the levels of corruption of the host country are low or significantly lower than those of the home country, the benefits of full ownership balance its costs (Di Guardo, Marrocu \& Paci, 2016). In countries with relatively good governance, i.e. "with a transparent, impartial and effective legal system that protects property and individual rights; with stable, credible and honest public institutions; and with government policies that promote open and free markets." (Hernández \& Nieto, 2015, p. 124), there is a better chance of firms entering through FDI (Globerman \& Shapiro, 2003). Foreign investors should be able to operate easier in environments in which the "rules of the game" are more clearly established (Cuervo-Cazurra \& Genc, 2011). When the host countries show significant lower levels of corruption than the home country, firms tend to adapt easier to those markets since they are entering less uncertain environments (Hernández \& Nieto, 2015). Thus, foreign investors will feel safer to invest alone without the need for a local partner (Di Guardo, Marrocu \& Paci, 2016). The benefits of total ownership balance the costs of the investment (Di Guardo, Marrocu \& Paci, 2016) and a higher level of control allows firms to reduce the costs of operating alone. Considering these arguments, we propose the following hypothesis:

Hypothesis 2a.Negative corruption distance between the home country (Portugal or Spain) and the host country moderates the 
effect of corruption distance, thus making smaller the ownership MNEs will seek in local subsidiaries.

Hypothesis 2b. Positive corruption distance between the home country (Portugal or Spain) and the host country heightens the effect of corruption distance, thus making greater the ownership MNEs will seek in local subsidiaries.

Figure 1 below depicts the proposed effects.

Figure 1 - Conceptual model

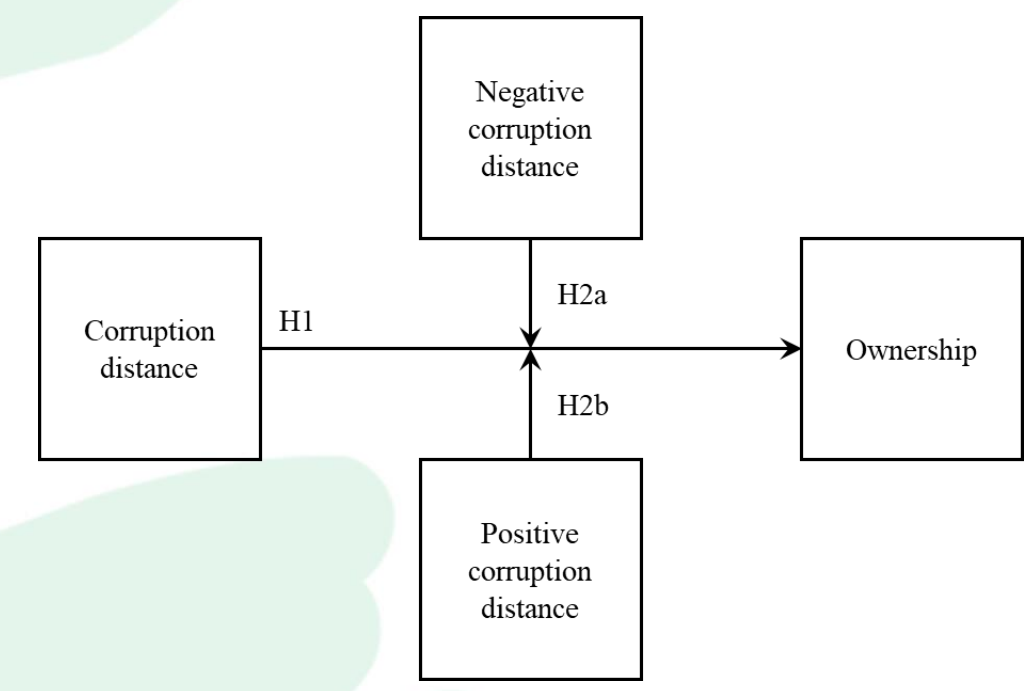

Source: Authors

\section{METHOD}

\section{Data and sample}

Data on ownership of Spanish and Portuguese MNEs on international subsidiaries were collected from Sabi - Sistema de Análise de Balanços Ibéricos, Bureau Van Dijk. This database contains comprehensive information on more than 2.5 million Spanish and Portuguese firms. To select our sample, we considered the foreign subsidiaries in which MNEs controlled at least $5 \%$ of ownership (under $5 \%$ equity the deals are considered for portfolio investment - cf. Chari and Chang (2009)). We also excluded subsidiaries from the financial sector and subsidiaries located in offshores, as well as Specific Purpose Entities (Ferreira et al., 2017). Finally, we include only the observations for which 2015 data are available. This selection process yields a sample of 3,941 subsidiaries (3,139 Spanish subsidiaries and 802 Portuguese subsidiaries), located in 68 countries. The main markets of destination for Portuguese MNEs are Spain (388 subsidiaries), France (95 subsidiaries) and Angola (49 subsidiaries). For the Spanish firms, Portugal (771 subsidiaries), Italy (317 subsidiaries) and France (310 subsidiaries) are the main destinations. Nevertheless, due to missing values in some variables, 2,786 observations were used to compute our models.

\section{Variables}

Ownership. The dependent variable in our empirical models is the ownership level of Spanish and Portuguese MNEs in subsidiaries located abroad. Ownership can take any value over $0 \%$ and less than or equal to $100 \%$. For this study, we excluded all observations where the ownership in local subsidiaries was lower than $5 \%$. Thus, our dependent variable may take any value between 5 and $100 \%$. Data on this variable were collected from Sabi database.

Corruption distance. The main explanatory variable of interest is corruption distance. Corruption distance is the difference in the levels of corruption between the home and host countries (Eden \& Miller, 2004). The level of corruption is the degree of corruption of the public sector perceived by analysts, businesspeople and experts in a specific country. Corruption distance is a continuous variable and it corresponds to the absolute difference between the inverse of the value of the Corruption Perceptions Index (CPI) for the home country (Portugal or Spain) and the inverse of the value of the CPI for the host country. The CPI is an aggregate indicator that combines data on corruption from 13 independent global institutions. Although some researchers have emphasized the need to use more experience-based 
measures of corruption, the CPI still offers a reliable measure of perceived corruption in different countries, which significantly affects investors' decisions (Mauro, 1995; Di Guardo, Marrocu \& Paci, 2016). The CPI ranges from 0 to 100 . A value of 0 means that the country is "highly corrupt" and 100 means the country is "very clean". For the sake of clarity, we use the inverse of the original index so that low values indicate low levels of corruption and high values indicate high levels of corruption (Di Guardo, Marrocu \& Paci, 2016).

Distance direction. This is a binary variable that takes the value 1 when the corruption distance is negative (i.e., the host country is more corrupt than the home country) and the value 0 when the corruption distance is positive (i.e., the host country is less corrupt than the home country). This variable allows us to identify the observations via the relative position of the host country compared to the home country in terms of corruption distance. The study constructs another independent variable - Corruption distance $\times$ Distance direction - by means of the interaction of these variables.

All estimated models include control variables that may influence the relationship between corruption distance and MNEs ownership strategies. These variables control for characteristics of the home country, characteristics of the host country and characteristics of the firms. The full sources and definitions of the variables are reported in Appendix I.

Home country GDP. We used the natural logarithm of home country GDP to control for the size of the country. We collected the data from World Development Indicators, a World Bank report covering a wide number of issues.

Geographic distance. Geographic distance increases transportation and telecommunication costs (Cuervo-Cazurra, 2008; Ferreira et al., 2017) that would discourage trade and favor FDI (CuervoCazurra, 2008). Therefore it is a factor that is likely to influence MNEs' investment decisions. We used the natural logarithm of the distance in $\mathrm{km}$ between Lisbon or Madrid and the capital of the host country.

Host country GDP. We used the natural logarithm of host country GDP to control for the host country economic size (Cuervo-Cazurra, 2008). Data were collected from World Development Indicators.

Host country risk. We also controlled for the risk of the host country, since it may influence MNEs ownership strategy (Di Guardo, Marrocu \& Paci, 2016). The indicator used is a composite index, computed by the Political Risk Service (PRS) group, which includes several dimensions, such as government stability, socioeconomic conditions, investment profile, internal and external conflicts, military in politics, religious tensions, law and order, ethnic tensions, democratic accountability and bureaucracy quality. This index ranges from 0 to 100 but once again we use the inverse of the original index so that a low score indicates lower risk and a high score indicates a high risk.

Host country unemployment. We used the unemployment rate of the host country to indicate the attractiveness of the country since investors are aware that employees will be more loyal when they lack other opportunities of employment (Godinez \& Liu, 2015). Data were collected from World Development Indicators.

Investing firm size. Operating revenue (thousands of euros) was used as a proxy for MNE size. It has been argued that larger firms have greater resource availability to acquire a larger ownership in other firms (Chari \& Chang, 2009). Data were collected from SABI.

Subsidiary size. The natural logarithm of the number of employees of the subsidiary was used as an indicator of the size of the subsidiary. Data were collected from SABI.

\section{Procedure}

We used an OLS (Ordinary Least Squares) regression model in this study to analyze the effects of corruption distance on international ownership strategies of Spanish and Portuguese firms. The OLS approach is appropriate given the use of continuous variables in the study. Moreover, we conducted a regression diagnostic using the variance inflation factors (VIF) to identify any potential problems associated with multicollinearity. The test did not suggest any serious problem of multicollinearity between variables since none of the VIF values exceeded 8.475, which is lower than the threshold of 10 used by most scholars (O'Brien, 2007).

The dependent variable is measured at the end of 2015, while the explanatory variables are measured one year earlier to account for the time lag that occurs between the decision regarding the ownership strategy and the actual implementation of the strategy.

The baseline model is specified as follows:

$$
\begin{aligned}
\text { Own_strat }_{\text {sub }}= & \beta_{0}+\beta_{1}\left(\text { Corruption distance }_{\text {od }}\right)+\beta_{2}(\text { Distance direction }) \\
& +\beta_{3}\left(\text { Corruption distance }_{\text {od }} * \text { Distance direction }\right)+\beta_{4}\left(\text { Cultural distance }_{\text {od }}\right) \\
& +\beta_{5}\left(\text { Corruption distance }_{\text {od }} * \text { Cultural distance }_{\text {od }}\right)+\beta_{6} \text { Ctrl }+\varepsilon
\end{aligned}
$$


where Own_strat sub $_{\text {is }}$ is the dependent variable which takes any value between 5 and $100 \% ; \beta_{0}$ is the constant; $\beta_{1}, \beta_{2}, \beta_{3}, \beta_{4}, \beta_{5}$ and $\beta_{6}$ are the coefficients of interest; Corruption distance od $_{\text {is }}$ is the absolute corruption distance between the $o$ th country of origin and the $d$ th destination country; Distance direction is a binary variable that takes the value 1 if corruption distance is negative and 0 if corruption distance is positive; (Corruption distance od Distance direction) presents the interaction between the absolute corruption distance between the oth country of origin and the $d$ th destination country and distance direction; Culturaldistance od is the cultural distance between the oth country of origin and the $d$ th destination country; (Corruption distance od $^{*}$ Cultural distance ${ }_{\text {od }}$ ) represents the moderation of the relationship between the absolute corruption distance between the oth country of origin and the $d$ th destination country and the cultural distance between the oth country of origin and the $d$ th destination country; Ctrl represents the control variables and $\varepsilon$ is the error term.

It should be noted that in those observations in which the host country displays a higher level of corruption than the home country, i.e., there is a negative corruption distance between both countries (Distance direction equals 1 ), the model is determined by:

$$
\begin{aligned}
\text { Own_strat }_{\text {sub }}= & \beta_{0}+\beta_{2}+\left(\beta_{1}+\beta_{3}\right)\left(\text { Corruption distance }_{\text {od }}\right)+\beta_{4}\left(\text { Cultural distance }_{\text {od }}\right) \\
& +\beta_{5} \text { Ctrl }+\varepsilon
\end{aligned}
$$

And in the opposite case, for those observations in which the host country displays a lower level of corruption than the home country, i.e., there is a positive corruption distance between both countries, (Distance direction equals 0 ), the model is determined by the following equation:

$$
\text { Own_strat }_{\text {gub }}=\beta_{0}+\beta_{1}\left(\text { Corruption distance }_{\text {od }}\right)+\beta_{4}\left(\text { Cultural distance }_{\text {od }}\right)+\beta_{5} \text { Ctrl }+\varepsilon
$$

In terms of interpreting the results, then, the coefficient of Corruption distance $\left(\beta_{1}\right)$ is used to test $\mathrm{H} 1 \mathrm{and} \mathrm{H} 2 \mathrm{~b}$ and the coefficients of Corruption distance and Corruption distance $\times$ Distance direction are used to test $\mathrm{H} 2 \mathrm{a}$ (requiring us to add $\beta_{1}$ and $\beta_{3}$ together). The coefficient of Distance direction $\left(\beta_{2}\right)$ represents the difference in the constant term of the observations of Distance direction with values equal to 0 and 1 . Hypothesis 1 and $2 b$ are supported if $\beta_{1}$ is positive and statistically significant. Hypothesis $2 \mathrm{a}$ is supported if $\left(\beta_{1}+\beta_{3}\right)$ is negative and statistically significant.

\section{RESULTS}

Table 1 presents the descriptive statistics and the correlation matrix for the variables included in the empirical analysis. Some of the variables show some degree of correlation which was expected, since many of the characteristics of a country tend to correlate (Cuervo-Cazurra, 2008). This level of correlation is also found in other studies (Uhlenbruck et al., 2006; Cuervo-Cazurra, 2008). Nevertheless, further testing revealed no evidence of multicollinearity: the VIFs range from 1.083 (investing firm size) to 7.667 (corruption distance) and 8.475 (distance direction). Therefore, despite some correlation between the corruption distance and the direction of the corruption distance, all VIF scores are below the usual cut-off of 10 thus indicating no multicollinearity problems (O’Brien, 2007). 
Table 1 - Descriptive statistics and correlations

\begin{tabular}{|c|c|c|c|c|c|c|c|c|c|c|c|c|c|c|}
\hline Variable & Mean & Std. Dev. & Min & Max & 1 & 2 & 3 & 4 & 5 & 6 & 7 & 8 & 9 & 10 \\
\hline 1. Ownership & 80.83 & 28.17 & 5.00 & 100.00 & 1 & & & & & & & & & \\
\hline $\begin{array}{l}\text { 2. Corruption } \\
\text { distance }\end{array}$ & 12.44 & 8.94 & 1.00 & 44.00 & $-0.03 \dagger$ & 1 & & & & & & & & \\
\hline $\begin{array}{l}\text { 3. Distance } \\
\text { direction }\end{array}$ & 0.50 & 0.50 & 0.00 & 1.00 & $-0.08^{* * * *}$ & $0.36^{* * *}$ & 1 & & & & & & & \\
\hline $\begin{array}{l}\text { 4. Home country } \\
\text { GDP (Ln) }\end{array}$ & 27.59 & 0.72 & 26.16 & 27.95 & $0.11^{* * *}$ & $0.11^{* * *}$ & $-0.30^{* * * *}$ & 1 & & & & & & \\
\hline $\begin{array}{l}\text { 5. Geographic } \\
\text { distance }\end{array}$ & 7.19 & 1.10 & 5.85 & 9.90 & $-0.03^{*}$ & $0.73^{* * *}$ & $0.34^{* * *}$ & $0.17^{* * *}$ & 1 & & & & & \\
\hline $\begin{array}{l}\text { 6. Host country } \\
\text { GDP (Ln) }\end{array}$ & 27.21 & 1.30 & 21.36 & 30.49 & 0.00 & $0.06^{* * *}$ & $-0.08^{* * *}$ & $-0.15^{* * *}$ & $0.08^{* * * *}$ & 1 & & & & \\
\hline $\begin{array}{l}\text { 7. Host country } \\
\text { risk }\end{array}$ & 23.74 & 5.60 & 7.00 & 47.00 & $-0.08^{* * *}$ & 0.02 & $0.36^{* * *}$ & $-0.08^{* * *}$ & $-0.18^{* * *}$ & $-0.10^{* * *}$ & 1 & & & \\
\hline $\begin{array}{l}\text { 8. Host country } \\
\text { unemployment } \\
\text { rate }\end{array}$ & 11.38 & 5.76 & 0.80 & 28.00 & -0.02 & $-0.53^{* * *}$ & $0.19^{* * *}$ & $-0.43^{* * *}$ & $-0.66^{* * *}$ & $-0.10^{* * *}$ & $0.32^{* * *}$ & 1 & & \\
\hline $\begin{array}{l}\text { 9. Investing firm } \\
\text { size }\end{array}$ & $632,880.78$ & $1,664,700.63$ & $-312,868.04$ & $19,077,481.00$ & $0.06^{* * *}$ & $0.06^{* * *}$ & $0.07^{* * *}$ & $0.04^{*}$ & $0.09^{* * * *}$ & $-0.03 \dagger$ & 0.01 & -0.01 & 1 & \\
\hline $\begin{array}{l}10 . \quad \text { Subsidiary } \\
\text { size }\end{array}$ & 3.44 & 1.80 & 0.00 & 11.59 & -0.01 & $0.18^{* * *}$ & -0.00 & $0.12^{* * *}$ & $0.23^{* * *}$ & 0.03 & $-0.04^{*}$ & $-0.21^{* * *}$ & $0.21^{* * *}$ & 1 \\
\hline
\end{tabular}

Significance levels: $\dagger p<0.1 ; * p<0.05 ; * * p<0.01 ; * * * p<0.001$. 
Table 2 presents the results of analyzing the influence of corruption distance on Spanish and Portuguese MNEs ownership strategies. Model 1 shows de analysis with only the control variables. Model 2 shows the analysis introducing the main explanatory variable, Corruption distance. The coefficient of this variable is positive and statistically significant at the 0.001 level. This supports Hypothesis 1, i.e., the greater the corruption distance between the home country, Portugal or Spain, and the host country the greater the ownership MNEs will seek in local subsidiaries. In model 3 we also include Distance direction and the interaction between Corruption distance and Distance direction (i.e., Regulative distance $\times$ Distance direction). As can be observed in model 3, the coefficient for Corruption distance is again positive and significant at the level 0.001. This finding provides support for Hypothesis $2 b$ by showing that when the distance is positive, corruption distance has a positive and significant impact on international ownership strategies, which means that MNEs seek a greater ownership in local subsidiaries $\left(\beta_{1}=0.26\right)$

In contrast, the coefficient for Corruption distance $\times$ Distance direction is negative and statistically significant at the level 0.001 $\left(\beta_{3}=-0.28\right)$. As previously mentioned, the effect of corruption distance for those observations in which the host country displays greater levels of corruption than the home country is equivalent to adding the coefficient of Corruption distance to the coefficient of Corruption distance $\times$ Distance direction. Thus, when the host country is more corrupt than the home country, the resulting coefficient is negative $\left(\beta_{1}+\beta_{3}=-0.02\right)$. This finding supports Hypothesis $2 \mathrm{a}$ by indicating that when the distance is negative, corruption distance has a negative impact on international ownership strategies, which means that MNEs seek a smaller ownership in local subsidiaries. We have also sought to discern the magnitude of the moderation effects (see Figure 2). We conclude that the moderating effect of the direction of corruption distance is more intense when the corruption distance is larger. In other words, when entering more corrupt countries (i.e. negative corruption distance direction), firms will require less ownership as the corruption distance increases.

Figure 2 - Moderation effects

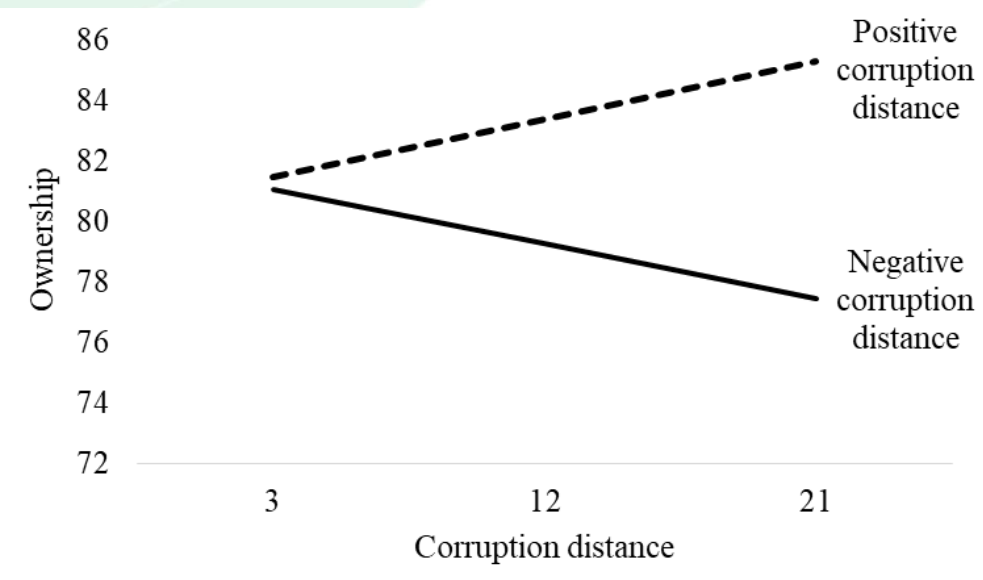

Source: Authors 
Table 2 - Results of the analysis of the impact of corruption distance on MNEs ownership strategies

\begin{tabular}{|c|c|c|c|}
\hline & \multicolumn{3}{|c|}{ Dependent variable: Ownership } \\
\hline & Model 1 & Model 2 & Model 3 \\
\hline Home country GDP & $0.12 * * *$ & $0.13^{* * *}$ & $0.14 * * *$ \\
\hline Host country GDP & 0.02 & 0.01 & -0.03 \\
\hline Host country risk & $-0.06^{* *}$ & $-0.07 * * *$ & 0.02 \\
\hline $\begin{array}{l}\text { Host country } \\
\text { unemployment rate }\end{array}$ & 0.03 & 0.05 & -0.03 \\
\hline Geographic distance & -0.02 & $-0.11 * *$ & $-0.14 * *$ \\
\hline Investing firm size & $0.09 * * *$ & $0.09 * * *$ & $0.08 * * *$ \\
\hline Subsidiary size & -0.03 & -0.02 & -0.02 \\
\hline Corruption distance & & $0.12 * * *$ & $0.26^{* * *}$ \\
\hline Distance Direction & & & $0.19 * * *$ \\
\hline $\begin{array}{l}\text { Corruption distance } \times \\
\text { Distance direction }\end{array}$ & & & $-0.28 * * *$ \\
\hline$R^{2}$ & 0.02 & 0.03 & 0.03 \\
\hline Adjusted $R^{2}$ & 0.02 & 0.03 & 0.03 \\
\hline$F$ & $9.50 * * *$ & $9.82 * * *$ & $9.28 * * *$ \\
\hline$N$ & 2,786 & 2,786 & 2,786 \\
\hline
\end{tabular}

Significance levels: $\dagger p<0.1 ;{ }^{*} p<0.05 ; * * p<0.01 ; * * * p<0.001$. 


\section{Post-hoc tests}

In addition to the tests presented above, we tested the 3 hypotheses for Spanish and Portuguese subsidiaries separately. For the Spanish subsidiaries, the results match the results presented above, supporting Hypotheses 1, 2a and 2b. For the Portuguese subsidiaries, none of the Hypotheses is supported. Since the home country characteristics (concerning corruption) are similar, we further investigated the sub-samples for firm-level characteristics (Table 3). We concluded the three firmlevel variables (Ownership, Investing firm size, and Subsidiary size) are significantly different in the Spanish and Portuguese sub-samples (for $\mathrm{p}<0.05$ ). This suggests other factors may influence the ownership strategy of Portuguese firms. We further elaborate on the discussion section.

Table 3 - Results of t-test for independent samples

\begin{tabular}{llllll}
\hline & Spain & & Portugal & t-test \\
\hline Variable & Mean & Std. Dev. & Mean & Std. Dev. & Sig. \\
\hline Ownership & 82.23 & 27.48190 & 74.53 & 29.86 & 0.000 \\
$\begin{array}{l}\text { Investing } \\
\text { firm size }\end{array}$ & $663,147.56$ & $1,776,891.04$ & $514,417.67$ & $1,115,529.97$ & 0.003 \\
$\begin{array}{l}\text { Subsidiary } \\
\text { size }\end{array}$ & 3.56 & 1.79 & 3.01 & 1.76 & 0.000 \\
\hline
\end{tabular}

\section{DISCUSSION AND CONCLUSION}

In this paper, we analyzed the influence of corruption distance on ownership strategies of Spanish and Portuguese MNEs. Existing literature on this subject is very limited, especially concerning the influence of the direction of corruption distance. The few empirical studies on this matter suggest that a higher corruption distance between home and host countries leads to a preference for WOS relative to JV. Our empirical analysis reveals that when corruption distance increases, MNEs seek a higher share of equity in local subsidiaries. Thus our results corroborate the conclusions of Tekin-Koru (2006) and Duanmu (2011). Moreover, the tests show that the direction of corruption distance matters: when the corruption distance is negative, MNEs seek a lower share of equity in local subsidiaries; in the opposite case, when the corruption distance between two countries is positive, MNEs tend to seek a higher share of equity in local subsidiaries. We therefore contribute to the literature on the effects of home-host countries differences, specifically advancing the understanding of the effect of corruption distance on ownership strategies. Furthermore, we shed light on the issue of asymmetrical home-host differences, by analyzing the direction of corruption distance.

When the host country is less corrupt than the home country, the environment is perceived as less risky and less uncertain, so firms feel safer to invest alone (Di Guardo, Marrocu \& Paci, 2016). A higher level of control over operations allows them to reduce the costs of operating alone (Madhok, 1997). Conversely, when the destination is significantly more corrupt that the home country, firms face higher risk and uncertainty. Corruption is considered institutionalized (Gabbioneta et al., 2013) and the institutional context encourages forms of direct corruption (Gabbioneta et al., 2013; Neu et al., 2013). From the investors perspective, especially for those from transparent countries, total ownership provides a greater control over the way the business is organized and conducted (Di Guardo, Marrocu \& Paci, 2016), in accordance with their values and principles (Gaur \& $\mathrm{Lu}, 2007)$. The intermediation by a local partner, who might be willing to engage in corruption activities, may be a source of conflict, representing for the firm additional costs of monitoring without specific advantages (Di Guardo, Marrocu \& Paci, 2016).

Although a greater corruption distance, in absolute terms, leads to greater shares of equity in local subsidiaries, when the corruption distance is negative, the share of equity sought by MNEs decreases, as suggested in Hypothesis 2a. This means that when the host country is more corrupt than the home country, increases in corruption distance between both countries lead to a lower share of equity sought by MNEs. Higher levels of corruption, compared to those of the home country, represent a higher degree of uncertainty for foreign investors, therefore higher risk and costs (Di Guardo, Marrocu \& Paci, 2016). A local partner, with market-knowledge, may speed up the adaptation of the firm to the local market and reduce the uncertainty and risk faced by the firm by sharing the costs of the investment and the control over the venture (Smarzynska \& Wei, 2002; Uhlenbruck et al., 2006). Moreover, investors can see a partnership as a means of obtaining the necessary skills and networks to navigate a corrupt environment (Canabal \& White, 2008; Brada, Drabek \& Perez, 2012).

When the host country shows lower levels of corruption than the home country, increases in 
corruption distance between both countries lead to greater shares of equity in local subsidiaries, as suggested in Hypothesis 2 b. Less corrupt environments are more institutionally developed and more favorable for foreign firms (Hernández \& Nieto, 2015). This happens because these environments are less uncertain, allowing firms to adapt more easily (Hernández \& Nieto, 2015). Foreign investors feel more confident about operating alone, without needing a local partner (Di Guardo, Marrocu \& Paci, 2016). The high costs of operating alone in an unknown market are compensated by the benefits of total ownership, such as a higher control over the way business is conducted and a higher investment return (Di Guardo, Marrocu \& Paci, 2016).

The post-hoc tests do not support our findings for the sub-sample of Portuguese MNEs. This is a somewhat puzzling conclusion since the corruption levels of Portugal and Spain are rather similar. Thus, the lack of effect is arguably due to firm-specific characteristics, which are significantly different. Portuguese firms seem to prefer significantly less ownership in foreign subsidiaries than Spanish firms (74.53 versus 82.23). This strategic decision may be influenced by other firm level characteristics such as industry relatedness which has been found to reduce the ownership level selected (Contractor et al., 2014). Also, the prior connectivity between Portugal and the host countries may reduce the knowledge difference and thus decrease the uncertainty (Di Guardo, Marrocu \& Paci, 2016). The geographical proximity to Spain and France, as well as historical colonial ties with Angola, the three main destinations, may contribute to explain why Portuguese MNEs require less ownership (Di Guardo, Marrocu \& Paci, 2016).

This study advances our knowledge of the impact of corruption distance and its direction, a subject that has so far received little discussion. Our findings show that distance direction matters and influences the decisions of MNEs regarding their international ownership strategies. This paper also provides a better understanding of how Spanish and Portuguese firms operate in international markets. Finally, this study is also important for managers. The results show that managers should evaluate foreign locations not only based on their corruption levels, but also on the difference and direction in corruption levels between their home country and the possible host country.

\section{Limitations and future research}

The empirical findings are subject to some limitations that emerge from the nature of the data presented. First, Spanish subsidiaries represent $80 \%$ of our sample and Portuguese ones only $20 \%$. A more evenly distributed sample could produce more accurate results. Second, we did not account for the industry to which the parent-firm and subsidiary belong. Some industries in various countries limit foreign equity participations. In that case, the ownership strategy is determined by legal restrictions and not by any of the variables used in this study. Finally, this is a crosssectional study that makes it impossible to explore the effects of ownership determinants over time. Future research can explore the impact of corruption distance on ownership strategies over time, in a longitudinal study.

In the future, it would be interesting to study the effect of corruption distance on the ownership strategy of firms with subsidiaries located in Portugal and Spain. Since corruption distance seems not to have any significant impact on ownership strategies of Portuguese MNEs, it would be also interesting for future work to analyze other institutional factors that may influence these decisions. The recognized impact of the institutional environment makes it necessary to explore the effect of institutional dimensions, such as the role of the government or the impact of legal issues, on the international ownership strategies of Portuguese firms. This effect is still little known.

The effect of corruption on MNEs' decisions has been receiving scholarly attention for a long time. Nevertheless, the full extent of corruption on MNEs' is still underexplored. We contribute to shed light on this issue, specifically analyzing the differences in corruption levels between home and host countries. We conclude that greater differences lead firms to seek a greater degree of control. Furthermore, we investigate the effect of asymmetric differences in corruption levels. Our findings reveal that when operating in a country which is more corrupt than the home country (i.e. negative corruption distance), the MNEs will seek a lower equity position. In face of increased uncertainty caused by a more corrupt environment, MNEs rely more on local partners with more knowledge of the institutional setting.

\section{REFERENCES}

Anderson, C., \& Tverdova, Y. (2003). Corruption, political allegiances, and attitudes toward government in contemporary democracies. American Journal of Political Science, 47(1): 91-109.

Anderson, E., \& Gatignon, H. (1986). Modes of foreign entry: A transaction cost analysis and propositions. Journal of international business studies, 17(3): 1-26.

Barkema, H., \& Vermeulen, F. (1998). International expansion through start-up or acquisition: A learning perspective. Academy of Management Journal, 41(1): 7-26. 
Beamish, P. (1985). The characteristics of joint ventures in developed and developing countries. Columbia Journal of World Business, 20(3): 13-19.

Bellos, S., \& Subasat, T. (2012). Corruption and foreign direct investment: A panel gravity model approach. Bulletin of Economic Research, 64(4): 565-574.

Brada, J., Drabek, Z., \& Perez, M. (2012). The effect of home-country and host-country corruption on foreign direct investment. Review of Development Economics, 16(4): 640-663.

Canabal, A., \& White, G. (2008). Entry mode research: Past and future. International Business Review, 17(3): 267-284.

Chari, M., \& Chang, K. (2009). Determinants of the share of equity sought in cross-border acquisitions. Journal of International Business Studies, 40(8): 1277-1297.

Cheung, S. (1996). A simplistic general equilibrium theory of corruption. Contemporary Economic Policy, 14(3): 1-5.

Contractor, F., Lahiri, S., Elango, B., \& Kundu, S. (2014). Institutional, cultural and industry related determinants of ownership choices in emerging market FDI acquisitions. International Business Review, 23(5): 931-941.

Cuervo-Cazurra, A. (2006). Who cares about corruption? Journal of International Business Studies, 37(6): 807-822.

Cuervo-Cazurra, A. (2008). Better the devil you don't know: Types of corruption and FDI in transition economies. Journal of International Management, 14(1): 12-27.

Cuervo-Cazurra, A. (2016). Corruption in international business. Journal of World Business, 51(1): 35-49.

Cuervo-Cazurra, A., \& Genc, M. (2008). Transforming disadvantages into advantages: developing-country MNEs in the least developed countries. Journal of International Business Studies, 39(6): 957-979.

Cuervo-Cazurra, A., \& Genc, M. (2011). Obligating, pressuring, and supporting dimensions of the environment and the non-market advantages of developing-country multinational companies. Journal of Management Studies, 48(2): $441-455$
Di Guardo, M., Marrocu, E., \& Paci, R. (2016). The effect of local corruption on ownership strategy in cross-border mergers and acquisitions. Journal of Business Research, 69(10): 4225-4241.

Duanmu, J-L. (2011). The effect of corruption distance and market orientation on the ownership choice of MNEs: evidence from China. Journal of International Management, 17(2): 162-174.

Eden, L., \& Miller, S. (2004). Distance matters: Liability of foreignness, institutional distance and ownership strategy. In Godinez Hitt, M. \& Cheng, J. (eds.) The Evolving Theory of the Multinational Firm. Volume 16, pp. 187-221, Bingley: Emerald Group Publishing Limited.

Ferreira, M., Vicente, S., Borini, F., \& Almeida, M. (2017). Degree of equity ownership in cross-border acquisitions of Brazilian firms by multinationals: a strategic response to institutional distance. Revista de Administração, 52(1): 59-69.

Gabbioneta, C., Greenwood, R., Mazzola, P., \& Minoja, M. (2013). The influence of the institutional context on corporate illegality. Accounting, Organizations and Society, 38(6): 484-504.

Gaur, A., \& Lu, J. (2007). Ownership strategies and survival of foreign subsidiaries: Impacts of institutional distance and experience. Journal of Management, 33(1): 84-110.

Globerman, S., \& Shapiro, D. (2003). Governance infrastructure and US foreign direct investment. Journal of International Business Studies, 34(1): 19-39.

Godinez, J., \& Liu, L. (2015). Corruption distance and FDI flows into Latin America. International Business Review, 24(1): 33-42.

Gupta, S., \& Abed, G. (2002). Governance, corruption, and economic performance. Washington DC: International Monetary Fund.

Habib, M., \& Zurawicki, L. (2002). Corruption and foreign direct investment. Journal of International Business Studies, 33(2): 291-307.

Hernández, V., \& Jesús Nieto, M. (2015). The effect of the magnitude and direction of institutional distance on the choice of international entry modes. Journal of World Business, 50(1): 122-132.

Holmes Jr, R., Miller, T., Hitt, M., \& Salmador, M. (2013). The interrelationships among informal 
institutions, formal institutions, and inward foreign direct investment. Journal of Management, 39(2): 531-566.

Karhunen, P., \& Ledyaeva, S. (2012). Corruption distance, anti-corruption laws and international ownership strategies in Russia. Journal of International Management, 18(2), 196-208.

Lambsdorff, J. (2003). How corruption affects persistent capital flows. Economics of Governance, 4(3): 229-243.

Luo, Y. (2001). Equity sharing in international joint ventures: An empirical analysis of strategic and environmental determinants. Journal of International Management, 7(1): 31-58.

Madhok, A. (1997). Cost, value and foreign market entry mode: The transaction and the firm. Strategic Management Journal, 18(1); 39-61.

Mauro, P. (1995). Corruption and growth. The Quarterly Journal of Economics, 110(3): 681-712.

Neu, D., Everett, J., Rahaman, A., \& Martinez, D. (2013). Accounting and networks of corruption. Accounting, Organizations and Society, 38(6): 505-524.

O'Brien, R. (2007). A caution regarding rules of thumb for variance inflation factors. Quality \& Quantity, 41(5): 673-690.

OECD. (2014). The rationale for fighting corruption. Paris: OECD.

Pajunen, K. (2008). Institutions and inflows of foreign direct investment: A fuzzy-set analysis. Journal of International Business Studies, 39(4): 652-669.

Shleifer, A., \& Vishny, R. W. (1993). Corruption. The Quarterly Journal of Economics, 108(3), 599-617.

Slangen, A., \& van Tulder, R. (2009). Cultural distance, political risk, or governance quality? Towards a more accurate conceptualization and measurement of external uncertainty in foreign entry mode research. International Business Review, 18(3): 276-291.
Smarzynska, B., \& Wei, S-J. (2000). Corruption and composition of foreign direct investment: Firmlevel evidence. NBER Working Paper w7969. Cambridge, MA: National Bureau of Economic Research.

Stopford, J., \& Wells Jr, L. (1972). Managing the multinational enterprise: organization of the firm and ownership of the subsidiary. New York, NY: Basic Books.

Suchman, M. C. (1995). Managing legitimacy: Strategic and institutional approaches. Academy of Management Review, 20(3): 571-610.

Svensson, J. (2005). Eight questions about corruption. The Journal of Economic Perspectives, 19(3): 19-42.

Tekin-Koru, A. (2006). Corruption and the ownership composition of the multinational firm at the time of entry: Evidence from Turkey. Journal of Economics and Finance, 30(2): 251-269.

Uhlenbruck, K., Rodriguez, P., Doh, J., \& Eden, L. (2006). The impact of corruption on entry strategy: Evidence from telecommunication projects in emerging economies. Organization Science, 17(3): 402-414.

Voyer, P., \& Beamish, P. (2004). The effect of corruption on Japanese foreign direct investment. Journal of Business Ethics, 50(3): 211224.

Wang, Y., \& Larimo, J. (2018). Ownership strategy and subsidiary survival in foreign acquisitions: The moderating effects of experience, cultural distance, and host country development. In: Verbeke, A., Puck , J. \& van Tulder, R. (Eds.). Distance in international business: concept, cost and value. volume 12, pp. 157-182, Bingley: Emerald Publishing.

Wei, S-J. (2000a). How taxing is corruption on international investors? Review of Economics and Statistics, 82(1): 1-11.

Wei, S-J. (2000b). Local corruption and global capital flows. Brookings Papers on Economic Activity, 31(2): 303-354. 
The Impact of Corruption Distance on Ownership Strategies of Spanish and Portuguese MNEs

Appendix I - Variables definitions and sources

\begin{tabular}{|c|c|c|c|}
\hline \multicolumn{2}{|c|}{ Variable } & Description & Source \\
\hline $\begin{array}{l}\text { Dependent } \\
\text { variable }\end{array}$ & $\begin{array}{l}\text { Ownership } \\
\text { strategy }\end{array}$ & $\begin{array}{l}\text { Share of equity sought by MNEs in local } \\
\text { subsidiaries. May take any value between } \\
5 \text { and } 100 \%\end{array}$ & $\begin{array}{l}\text { Sabi - Sistema de } \\
\text { Análise de Balanços } \\
\text { Ibéricos, Bureau Van } \\
\text { Dijk }\end{array}$ \\
\hline \multirow{3}{*}{$\begin{array}{l}\text { Explanatory } \\
\text { variables }\end{array}$} & $\begin{array}{l}\text { Corruption } \\
\text { distance }\end{array}$ & $\begin{array}{l}\text { Absolute difference between the inverse } \\
\text { of the value of the CPI for Portugal or }\end{array}$ & $\begin{array}{l}\text { Corruption Perceptions } \\
\text { Index 2014- }\end{array}$ \\
\hline & & $\begin{array}{l}\text { Spain and the inverse of the value of the } \\
\text { CPI for the host country }(0=\text { highly } \\
\text { corrupt to } 100=\text { very clean), } 2014\end{array}$ & $\begin{array}{l}\text { Transparency } \\
\text { International }\end{array}$ \\
\hline & $\begin{array}{l}\text { Distance } \\
\text { direction }\end{array}$ & $\begin{array}{l}\text { Dummy }=1 \text { when the corruption distance } \\
\text { is negative and } 0 \text { when it's positive }\end{array}$ & $\begin{array}{l}\text { Corruption Perceptions } \\
\text { Index 2014- } \\
\text { Transparency } \\
\text { International }\end{array}$ \\
\hline \multirow[t]{7}{*}{$\begin{array}{c}\text { Control } \\
\text { variables }\end{array}$} & $\begin{array}{l}\text { Home country } \\
\text { GDP }\end{array}$ & $\begin{array}{l}\text { Natural log of home country gross } \\
\text { domestic product in millions of US\$, } \\
2014\end{array}$ & $\begin{array}{l}\text { World Development } \\
\text { Indicators, World Bank }\end{array}$ \\
\hline & $\begin{array}{l}\text { Geographic } \\
\text { distance }\end{array}$ & $\begin{array}{l}\text { Natural log of the distance in } \mathrm{km} \text { between } \\
\text { Lisbon or Madrid and the capital city of } \\
\text { the host country }\end{array}$ & \\
\hline & $\begin{array}{l}\text { Host country } \\
\text { GDP }\end{array}$ & $\begin{array}{l}\text { Natural log of host country gross } \\
\text { domestic product in millions of US\$, } \\
2014\end{array}$ & $\begin{array}{l}\text { World Development } \\
\text { Indicators, World Bank }\end{array}$ \\
\hline & $\begin{array}{l}\text { Host country } \\
\text { risk }\end{array}$ & $\begin{array}{l}\text { Inverse of the Risk Index }(1=\text { high risk to } \\
100=\text { low risk }), 2014\end{array}$ & PRS \\
\hline & $\begin{array}{l}\text { Host country } \\
\text { unemployment } \\
\text { rate }\end{array}$ & $\begin{array}{l}\text { Percentage of working-age population } \\
\text { without employment, } 2014\end{array}$ & $\begin{array}{l}\text { World Development } \\
\text { Indicators, World Bank }\end{array}$ \\
\hline & $\begin{array}{l}\text { Investing firm } \\
\text { size }\end{array}$ & $\begin{array}{l}\text { Investing firm operating revenue in } \\
\text { thousands of euros }\end{array}$ & $\begin{array}{l}\text { Sabi - Sistema de } \\
\text { Análise de Balanços } \\
\text { Ibéricos, Bureau Van }\end{array}$ \\
\hline & Subsidiary size & $\begin{array}{l}\text { natural logarithm of the number of } \\
\text { employees of the subsidiary }\end{array}$ & $\begin{array}{l}\text { Dijk } \\
\text { Sabi - Sistema de } \\
\text { Análise de Balanços } \\
\text { Ibéricos, Bureau Van } \\
\text { Dijk }\end{array}$ \\
\hline
\end{tabular}

